\title{
Perlindungan Hukum Terhadap Hak-Hak Konsumen Terkait Tiket Pesawat Yang Dibatalkan Maskapai Penerbangan Masa Pandemi Covid-19
}

\author{
Ferdiana Mailawati ${ }^{1}$, Sri Wahyuni ${ }^{2 *}$ \\ 12Universitas Bhayangkara Jakarta Raya \\ *Korespondensi: sri.wahyuni@dsn.ubharajaya.ac.id
}

Article info

Received: Oct 24, $2021 \quad$ Revised: Nop 29, $2021 \quad$ Accepted: Dec 5, $2021 \quad$ Published: Dec 9, 2021

DOI: https://doi.org/10.31599/krtha.v15i2.859

Keywords : $\quad$ Legal Protection, Consumer Rights, Cancellation of Airline Tickets

Abstract : Air transportation is one of the means of air transportation that is needed by someone who wants to travel between islands and even between countries with long enough distances that can be traveled in a relatively faster time when compared to other transportation. However, when consumers have ordered and paid for airline tickets with certain destinations according to their needs and needs, when the COVID-19 pandemic hit Indonesia and even almost all countries in the world experienced it, there were several policies carried out by the government of the Republic of Indonesia in order to prevent the transmission of the virus. This has an impact on aviation transportation. so that there are flight transportation schedules that have been cancelled. This study will answer the question of how the legal protection of consumer rights related to the cancellation. Normative juridical research method with a legal approach, namely regulations related to consumer and aviation protection that apply in Indonesia. The results of this study analyze the legal protection of consumer rights related to compensation when the flight ticket that has been ordered is canceled by the airline between the facts and the relevant regulations are appropriate.

Kata kunci : Perlindungan Hukum, Hak-Hak Konsumen, Pembatalan Tiket Pesawat

Abstrak : Angkutan penerbangan merupakan salah satu alat transportasi udara yang dibutuhkan seseorang ingin melakukan perjalanan antar pulau bahkan antar negara dengan jarak cukup jauh dapat di tempuh dengan waktu relatif lebih cepat apabila dibandingkan dengan transportasi lainnya. Namun ketika konsumen telah memesan dan membayar tiket pesawat terbang dengan tujuan tertentu sesuai dengan keperluan dan kebutuhan, ketika terjadi pandemi covid-19 yang melanda Indonesia bahkan hampir diseluruh negara didunia juga mengalaminya, ada beberapa kebijakan yang dilakukan oleh pemerintah Republik Indonesia dalam rangka mencegah penularan virus tersebut yang berdampak pada angkutan penerbangan. sehingga ada jadwal angkutan penerbangan yang mengalami pembatalan. Penelitian ini akan menjawab pertanyaan bagaimana perlindungan hukum terhadap hak-hak konsumen terkait adanya pembatalan tersebut. Metode Penelitian yuridis normatif dengan pendekatan undang-undang yakni peraturanperaturan terkait perlindungan konsumen dan penerbangan yang berlaku di Indonesia. Hasil dari penelitan ini menganalisis perlindungan hukum terhadap hak-hak konsumen terkait ganti kerugian ketika tiket pesawat yang telah dipesan 
tersebut dibatalkan oleh pihak maskapai penerbangan antara fakta dan peraturan terkait adalah telah sesuai.

\section{PENDAHULUAN}

Transportasi angkutan udara yang menggunakan pesawat terbang adalah salah satu sektor yang berperan dalam mendukung kegiatan perekonomian Indonesia. Diantara peran tersebut adalah jasa pengangkutan tranportasi udara sebagai penghubungan antar dan antar negara. ${ }^{1}$ Di samping itu transportasi udara sangat berhubungan dengan tingkat produktivitas, karena tingginya pergerakan manusia menandakan produktivitas yang juga positif. $^{2}$

Menurut Purwosutjipto pengangkutan merupakan perjanjian timbal balik antara pihak pengangkut dengan pihak pengirim, dimana pengangkut mengikatkan diri untuk menyelenggarakan pengangkutan barang dan atau orang dari satu tempat ke tempat lain dengan tujuan selamat, sedangkan pihak pengirim mengikatkan diri dengan membayar sejumlah uang angkutan. ${ }^{3}$ Secara garis besar, transportasi angkutan dapat diklasifikasikan antara lain angkutan darat melalui jalan raya dan kereta api, angkutan laut, angkutan udara.

Selanjutnya perkembangan mengenai jumlah perusahaan penerbangan merupakan satu hal yang menguntungkan pengguna jasa atau konsumen transporatsi udara karena menjadi banyak pilihan. Perusahaan bersaing dengan tujuan untuk menarik konsumen dengan menawarkan tarif yang murah atau bisa juga dengan cara menawarkan bonus. Namun seringkali, tarif yang murah tersebut menurunkan segi kualitas pelayanan, bahkan ada pula yang mengkhawatirkan menyebabkan berkurangnya kualitas pemeliharaan (maintenance) terhadap pesawat yang akan berdampak terhadap keselamatan penerbangan dan kurangnya keamanan, kenyamanan dan perlindungan bagi konsumen. ${ }^{4}$

Pada dasarnya dalam kegiatan pengangkutan udara terdiri dari dua pihak, antara lain pihak pengangkut seperti perusahaan atau maskapai penerbangan dan pihak pengguna jasa atau konsumen. Para pihak terikat suatu perjanjian yang disebut sebagai perjanjian pengangkutan. Perjanjian merupakan hubungan hukum yang memiliki sifat keperdataan maka di dalamnya terkandung hak dan kewajiban yang harus dilaksanakan dan dipenuhi

${ }^{1}$ Soekardono, Hukum Dagang Jilid 1, Jakarta: Rajawali Press, 1981, hlm. 4.

2 M.N.Nasution, Manajemen Transportasi, Bogor: Ghalia Indonesia, 2007, hlm. 2.

3 H. M. N. Purwosutjipto, Pengertian Pokok Hukum Dagang Indonesia 3: Hukum Pengangkutan, Yogyakarta: Djambatan, 1991, hlm. 2.

${ }^{4}$ Saefullah Wiradipradja, "Tanggung Jawab Perusabaan Penerbangan Terbadap Penumpang Menurut Hukum Udara Indonesia”, Jurnal Hukum Bisnis Vol 25, 2006, hlm. 5-6. 
para pihak, disebut dengan istilah "prestasi". ${ }^{5}$ Mengenai Hak dan kewajiban para pihak dalam dokumen perjanjian pengangkutan. ${ }^{6}$

Angkutan udara mempunyai peranan penting dalam kehidupan khususnya dalam menjalankan roda perekonomian dalam rangka memenuhi kebutuhan hidup. Namun kenyatannya saat ini dunia sedang menghadapi krisis pandemi Coronavirus Disease 2019 atau biasa disebut dengan Covid-19. Selanjutnya Presiden Joko Widodo menyatakan Covid-19 sebagai bencana nasional dengan mengeluarkan Keputusan Presiden Nomor 12 Tahun 2020 Tentang Penetapan Bencana Non Alam Penyebaran Coronavirus Disease 2019 (Covid19) Sebagai Bencana Nasional (Keppres 12/2020) yang telah dikeluarkan pada tanggal 13 April 2020, ${ }^{7}$ kemudian menyusul adanya keputusan World Health Organization (WHO) yang menyatakan bahwa Covid-19 merupakan pandemi global pada tanggal 11 Maret 2020.

Banyaknya angka kematian akibat dampak adanya pandemi Covid-19 membuat sejumlah negara didunia mengambil langkah-langkah sebagai upaya atau usaha pencegahan seperti kebijakan penguncian (lockdown) atau Pembatasan Sosial Berskala Besar (PSBB) atau Pemberlakuan Pembatasan Kegiatan Perkantoran (PPKM) dengan tujuan untuk membatasi interaksi fisik masyarakat luas. Beberapa kebijakan tersebut berdampak pada aktivitas ekonomi serta mobilitas masyarakat dunia dan juga masyarakat Indonesia pada khususnya. ${ }^{8}$

Pemerintah Indonesia telah memberlakukan larangan operasional sejumlah moda transportasi dan menutup seluruh fasilitas terkait. Dalam rangka mencegah penularan wabah yang akan semakin meluas. Hal tersebut berdampak langsung terhadap bisnis jasa transportasi udara dengan dibatalkannya penerbangan dan diberlakukan pengembalian uang tiket (refund). ${ }^{9}$ Mengenai istilah Refund merupakan pengembalian uang akibat adanya pembatalan atau dibatalkannya atau tidak dilaksanakan satu kewajiban oleh salah satu pihak sehingga mengharuskan pengembalian sejumlah uang yang telah diterima dari pihak

5 Yunita Larasati, Indah Dewi Megasari, Hanafi, “Tanggung Jawab Maskapai Penerbangan Terbadap Penumpang Pesawat Akibat Pembatalan Penerbangan Menurut Undang-Undang Nomor 1 Tabun 2009 Tentang Penerbangan”, Makalah, Program Studi Ilmu Hukum, Fakultas Hukum, Universitas Islam Kalimantan Muhammad Arsyad Al-Banjary Banjarbaru, Kalimantan Selatan, hlm. 3.

${ }^{6}$ Ibid.

${ }^{7}$ Herman Herman et al., "Tinjauan Yuridis Mengenai Dampak Covid-19 Terbadap Pemutusan Hubungan Kerja," Halu Oleo Law Review Vol. 4 Nomor 2, 2020, hlm. 158.

${ }^{8} \mathrm{CNN}$ Indonesia, "Lika Liku Istilah Jokowi Dari PSBB Hingga Mini Lockdown", https://www.cnnindonesia.com/nasional/20200930061801-20-552537/lika-liku-istilah-jokowi-dari-psbbhingga-mini-lockdown, diakses pada tanggal 1 April, 2021, pukul 19.45 WIB.

9 B Budimah, "Pembatalan Tiket oleh Calon Penumpang Maskapai Penerbangan di Indonesia," Maleo Law Journal 2, No. 1, 2018, hlm. 19. 
lain. ${ }^{10}$ Refund dapat juga dikategorikan sebagai wanprestasi sebagaimana tertulis dalam Pasal 1243 KUHPerdata.

Menurut Pasal 4 huruf h Undang-Undang Nomor 8 Tahun 1999 tentang Perlindungan Konsumen (UUPK) mengatur perihal konsumen yang berhak untuk mendapatkan kompensasi atau ganti rugi dan atau pengganti, jika barang dan atau jasa yang diterima tidaklah sesuai dengan perjanjian atau tidak sebagaimana mestinya. ${ }^{11}$

Pasal 9 ayat (1) huruf f Permenhub No. PM 89 Tahun 2015 mengatur mengenai penanganan keterlambatan penerbangan angkutan udara niaga berjadwal di Indonesia dan badan usaha angkutan udara wajib mengalihkan ke penerbangan berikutnya atau dengan mengembalikan seluruh biaya tiket. ${ }^{12}$ Pasal 6 ayat (1) huruf b Permenhub No. 185 Tahun 2015 mengatur mengenai standar pelayanan pemesanan tiket (reservation) sebagaimana dimaksud dalam Pasal 4 ayat (1) huruf b.

Berdasarkan ketentuan tersebut, maka jelas terhadap pembatalan penerbangan yang berakibat pada kerugian konsumen, maka pelaku usaha berkewajiban untuk memberikan hak konsumen penerbangan berupa pembatalan tiket dan jangka waktu pengembalian uang tiket atau bisa kita mengenal dengan istilah refund ticket. Permasalahan timbul ketika pembatalan penerbangan akibat pandemi Covid-19, pihak pelaku usaha penerbangan memberikan hak konsumen dalam pengembalian uang tiket (refund) tidak dalam bentuk uang, melainkan dalam bentuk voucher. Hal tersebut sebagaimana yang terjadi pada kasus pengembalian dana dilakukan menggunakan FOP Voucher di maskapai Lion Air.

Dalam kasus tersebut, konsumen Lion Air bernama Praditya sudah memesan tiket penerbangan menggunakan Lion Air dan Batik Air dengan rute Aceh - Jakarta. Praditya bersama keluarganya memesan tiket dengan jumlah 44 (empat puluh empat) seat dengan total Rp 60.000.000,- (enam puluh juta rupiah) untuk keberangkatan pada 12 April dan 13 April 2020. Oleh karena dengan adanya pandemi Covid-19, maka tiket tersebut dibatalkan keberangkatannya. Disisi lain, berdasarkan kebijakan Lion Air yang tertuang dalam surat itu bernomor 003/AGTNEWS/JOGAM/IV/2020JT/IW/ID, menyatakan bahwa pihak maskapai akan memberikan voucher yang dapat digunakan pada saat

${ }^{10} \mathrm{Ibid}$.

11 Pasal 4 huruf h Undang-Undang Nomor 8 Tahun 1999 tentang Perlindungan Konsumen.

12 Pasal 9 ayat (1) huruf f Peraturan Menteri Perhubungan Nomor PM 89 Tahun 2015 Tentang Penanganan Keterlambatan Penerbangan (Delay Management) Pada Badan Usaha Angkutan Udara Niaga Berjadwal di Indonesia. 
penerbangan pada waktu yang lain. ${ }^{13}$ Hal yang sama juga terjadi pada kasus yang dialami oleh Margareta Hanny.

Dalam kasus tersebut, Margareta Hanny sebagai pihak konsumen maskapai Garuda Indonesia berharap pengembalian sejumlah uang atas tiket pesawat yang telah dibatalkannya akibat pandemi Covid-19. Namun kebijakan dari pihak maskapai Garuda Indonesia sama dengan kebijakan maskapai Lion Air yaitu refund atau penngembalian tiket pesawat yang dibatalkan adalah berupa pemberian voucher. ${ }^{14}$

Berdasarkan kedua kasus di atas, maka terlihat bahwa pengembalian dana pada tiket pesawat berupa voucher tidak berdasarkan kesepakatan dari kedua belah pihak (dalam hal ini pihak maskapai dan pihak konsumen). Hal tersebut tentunya bertentangan dengan Pasal 1321 KUHPerdata yang mengatur bahwa "tiada sepakat yang sah apabila diberikan karena paksaan". ${ }^{15}$ tapi berdasarkan pada kebijakan pelaku usaha.

Ada beberapa Penelitian tentang pembatalan tiket pesawat, yang telah dilakukan oleh Putri Humaira tahun 2019 mengenai Sistem Refund Pada Pembatalan Tiket Penerbangan Dalam Perspektif Akad Al- Ijärah Bi Al-Manfa'ah (Suatu Penelitian di Agen Travel Kecamatan Kuta Alam Kota Banda Aceh). Fokus penelitiannya terkait dengan sistem refund pembatalan tiket penerbangan berdasarkan Permenhub No.25 Tahun 2008 tentang Penyelenggaraan Angkutan Udara dan jangka waktu pengembalian biaya tiket penerbangan yang dilakukan oleh agen travel kepada pihak penumpang dan implementasi sistem refund pada saat pembatalan tiket penerbangan dalam perspektif akad al-ijärah bialmanfa'ah. ${ }^{16}$

Penelitian kedua oleh Rizki Diah Nasrunisa tahun 2018 dengan judul penelitian Akibat Hukum Pembatalan Penerbangan Karena Overseat Oleh Maskapai Lion Air (Studi Putusan Nomor $471 \mathrm{PK} / \mathrm{Pdt} / 2017)$. Fokus penelitian terkait dengan tanggung jawab pihak maskapai selaku pihak pelaku usaha dalam perkara keterlambatan penerbangan,

13 Muhammad Chairul Anwar, "Curbat Penumpang Pesawat Batal Terbang Uang Pun Nyangkut", https://www.cnbcindonesia.com/news/20200420174532-4-153199/curhat-penumpang-pesawat-batalterbang-uang-pun-nyangkut., diakses pada tanggal 14 Mei 2021, pukul 21.08 WIB.

${ }^{14}$ Nicholas Ryan Aditya, "Netizen Kelubkan Refund Tiket Tiket Pesawat Berupa Voucher Asosiasi Harap Maskapai”, https://travel.kompas.com/read/2020/04/27/083000327/netizen-keluhkan-refund-tiketpesawat-berupa-voucer-asosiasi-harap-maskapai?page=all., diakses pada tanggal 14 Mei 2021, pukul 22.06 WIB

15 Pasal 1321 Kitab Undang-Undang Hukum Perdata.

16 Putri Humaira, "Sistem Refund Pada Pembatalan Tiket Penerbangan Dalam Perspektif Akad Al- Ijärah Bi Al-Manfa'ah (Suatu Penelitian di Agen Travel Kec. Kuta Alam Kota Banda Aceh)”, Skripsi Fakultas Syariah dan Hukum Universitas Islam Negeri Ar-Raniry Darussalam-Banda Aceh, 2019. 
serta bagaimana tanggung jawab pihak maskapai penerbangan Lion Air dalam kasus antara Lion Air vs Rolas Budiman Sitinjak. ${ }^{17}$

Penelitian ketiga oleh Rahmawati tahun 2015 dengan judul penelitian "Tanggung Jawab Maskapai Penerbangan Terhadap Ganti Kerugian Pengembalian Uang Atas Pembatalan Penerbangan Secara Sepihak". Fokus penelitian tersebut adalah tanggung jawab penyedia jasa kepada konsumen penerbangan jika terjadi pembatalan penerbangan secara sepihak serta bagaimana penyelesaian sengketa antara penyedia jasa dengan konsumen penerbangan apabila terjadi pembatalan penerbangan secara sepihak. ${ }^{18}$

Berdasarkan penelitian-penelitian sebelumnya yang tersebut di atas, maka terlihat perbedaan dengan penelitian yang Penulis lakukan. Perbedaan tersebut terdapat pada objek penelitiannya, yaitu hak-hak konsumen terkait ganti rugi terhadap konsumen yang tiket pesawatnya dibatalkan pada masa pandemi Covid-19.

Penelitian ini membahas mengenai perlindungan hukum hak-hak terkait ganti rugi terhadap konsumen yang tiket pesawatnya dibatalkan pada masa pandemi Covid-19. Pembelian tiket pesawat tentunya harus sesuai dengan hukum yang berlaku sehingga dapat terwujud kepastian hukum dan perlindungan hukum terhadap hak-hak konsumen, termasuk pula terkait dengan mekanisme pembatalan tiket pesawat karena pandemi virus Covid-19. Namun demikian, dalam praktiknya, terdapat pengembalian dana tiket yang tidak berupa uang cash, tetapi dalam bentuk voucher yang berpotensi merugikan konsumen selaku pembeli. Pengembalian dana (refund) tiket yang tidak berupa uang cash, tetapi dalam bentuk voucher ini berpotensi melanggar ketentuan dalam Pasal 1320 KUHPerdata mengenai keabsahan perjanjian, Pasal 4 huruf a UUPK jo Pasal 7 huruf g jo Pasal 19 ayat (2) UUPK. Fokus penelitian ini mengenai bagaimana perlindungan hukum hak-hak konsumen terkait pembatalan tiket pesawat oleh maskapai penerbangan pada masa pandemi Covid-19.

\section{METODE}

Metode pendekatan yang digunakan dalam penelitian ini adalah yuridis normatif (hukum normatif) yaitu penelitian hukum yang dilakukan dengan cara meneliti bahan pustaka atau data sekunder, sehingga akan dilakukan penelitian terhadap bahan-bahan kepustakaan. ${ }^{19}$

${ }^{17}$ Rizki Diah Nasrunisa, "Akibat Hukum Pembatalan Penerbangan Karena Overseat Oleh Maskapai Lion Air (Studi Putusan Nomor 471 PK/Pdt/ 2017)”, Skripsi Fakultas Syariah dan Hukum Universitas Islam Negeri Syarif Hidayatullah Jakarta, 2018.

${ }^{18}$ Rahmawati, "Tanggung Jawab Maskapai Penerbangan Terhadap Ganti Kerugian Pengembalian Uang Atas Pembatalan Penerbangan Secara Sepihak", Tesis Program Pascasarjana Univeritas Hasanuddin Makassar, 2015.

${ }^{19}$ Soerjono Soekanto dan Sri Mamudji, Penelitian Hukum Normatif, Suatu Tinjauan Singkat, Jakarta: PT. Raja Grafindo Persada, 2006, hlm. 13. 
Bahan-bahan tersebut berupa konsep, teori, ketentuan peraturan-peraturan terkait permasalahan dalam penelitian yang akan digunakan sebagai sumber data utama penelitian. Penelitian ini menekankan pada penelitian kepustakaan mengenai ganti rugi terhadap konsumen terkait tiket pesawat yang dibatalkan maskapai penerbangan pada masa pandemi covid-19.

Penelitian ini, menggunakan pendekatan undang-undang (statute approach) dan pendekatan kasus. Dalam metode pendekatan perundang-undangan pemahaman akan hierarki dari perundang-undangan adalah penting mengingat hierarki menunjukkan suatu struktur dan pada struktur tersebut, masing-masing bagian dalam struktur terdapat kedudukannya masing-masing, sehingga dengan memahami hierarki dari suatu perundang-undangan maka akan terlihat kedudukan dari peraturan perundang-undangan yang satu dengan peraturan lainnya. ${ }^{20}$

Diantaranya KUHPerdata, UUPK, Permenhub No. PM 185 Tahun 2015 dan Permenhub No. PM 89 Tahun 2015. Penelitian ini fokus kepada peraturan perundangundangan tersebut guna dapat memahami substansi yang mendasari serta latar belakang perundangan yang berkaitan dalam rangka tinjauan hukum tentang ganti rugi terhadap konsumen terkait tiket pesawat yang dibatalkan maskapai penerbangan pada masa pandemi covid-19. Pada pendekatan kasus, dalam hal ini kasus yang diteliti adalah kasus terkait dengan ganti rugi atas tiket pesawat yang dibatalkan maskapai penerbangan pada masa pandemi covid-19.

Jenis data yang digunakan adalah data sekunder dengan didukung oleh data primer. Pada data primer, dengan mewawancarai langsung kepada pihak maskapai Garuda dan Lion Air serta dengan pihak travel, dan untuk data sekunder diperoleh melalui penelusuran kepustakaan atau dari dokumen resmi seperti buku-buku terkait. Pada data sekunder terbagi menjadi 3 (tiga), yaitu:

Pertama, Bahan Hukum Primer, yaitu sumber hukum yang menjadi pengikat/landasan hukumnya seperti: UUD 1945, KUHPerdata, UUPK, PerMenHub No.PM 89 Tahun 2015 dan PerMenHub No. PM 185 Tahun 2015. Kedua, Bahan hukum sekunder, seperti bahan yang berupa buku-buku, harian/majalah dan karya tulis ilmiah. Ketiga, Bahan hukum tersier, seperti kamus-kamus hukum, ensiklopedia, dan bibliografi.

Metode pengumpulan data yang digunakan dalam penelitian ini seperti studi kepustakaan dan juga studi lapangan. Pada studi lapangan, perolehan data juga melalui wawancara kepada pihak maskapai Garuda dan Lion Air serta dengan pihak travel. Dalam

${ }^{20}$ Peter Mahmud Marzuki, Penelitian Hukum, Jakarta: Kencana, 2009, hlm. 93. 
studi kepustakaan ini yang dilakukan adalah mempelajari dan membaca buku-buku, majalah, media cetak dan media elektronik yang mengulas mengenai hukum tentang ganti rugi terhadap konsumen terkait tiket pesawat yang dibatalkan maskapai penerbangan pada masa pandemi Covid-19.

Bentuk hasil penelitian sesuai dengan tipe penelitian yang bersifat deskriptif adalah menguraikan mengenai fakta yang nyata terjadi terhadap pelaksanaan dari peraturan perundang-undangan di bidang pembatalan tiket pesawat dan perlindungan konsumen.

\section{PEMBAHASAN}

\section{Perlindungan Hukum Terhadap Hak-Hak Konsumen Yang Tiket Pesawatnya Dibatalkan Pada Masa Pandemi Covid-19 Berdasarkan Pasal 4 UUPK}

Menurut Pasal 2 UUPK menyatakan Perlindungan konsumen berasaskan manfaat, keadilan, keseimbangan, keamanan dan keselamatan konsumen, serta kepastian hukum. ${ }^{21}$ Upaya perlindungan konsumen dalam penggunaan jasa penerbangan berdasarkan UUPK yang dimaksud dengan perlindungan konsumen segala upaya yang menjamin adanya kepastian hukum untuk memberikan perlindungan kepada konsumen. Berdasarkan Pasal 3 UUPK.

Selanjutnya, berdasarkan Pasal 1 angka 2 UUPK, menyatakan bahwa konsumen merupakan setiap orang pemakai barang dan/atau jasa, untuk digunakan kepentingan diri sendiri, keluarga, orang lain dan tidak diperdagangkan. Definisi lain dikemukakan oleh Kotler sebagai berikut:"Consumers are individuals and households for personal use, producers are individual and organizations buying for the purpose of pruducing." 22 Apabila terjadi wanprestasi berupa keterlambatan, yang disebabkan oleh kelalaian pelaku usaha, yaitu maskapai penerbangan, berdasarkan Pasal 4 UUPK, diantaranya mengatur mengenai Hak atas kenyamanan, dalam hal ini konsumen berhak atas kenyamanan, hak keamanan dan keselamatan mengkonsumsi barang dan atau jasa, dalam hal ini konsumen juga memiliki hak atas keamanan serta keselamatan. Hak untuk memilih barang dan atau jasa dan juga mendapatkan barang dan atau jasa sesuai dengan nilai tukar, dalam hal ini jelas dikatakan dalam undang-undang bahwa konsumen memiliki hak dalam memperoleh jasa angkutan sesuai dengan nilai tukarnya dan kondisi serta jaminan yang dijanjikan serta Hak untuk mendapatkan advokasi, perlindungan, dan upaya penyelesaian sengketa perlindungan konsumen secara patut. Selanjutnya Hak untuk mendapatkan kompensasi atau ganti rugi

${ }^{21}$ AZ. Nasution, Op.Cit., hlm. 14.

${ }^{22} \mathrm{Az}$. Nasution, Ibid., hlm. 44. 
atau penggantian, juga diatur dalam UUPK, ketika barang dan atau jasa yang diterima tidak sesuai dengan perjanjian atau apabila tidak sebagaimana mestinya;

Berdasarkan hal tersebut maka konsumen berhak mendapat ganti rugi dari pelaku usaha. Dalam UUPK ada tiga pasal yang mengatur mengenai tanggung jawab produk, yaitu Pasal 19, Pasal 23 dan Pasal 28. Pada Pasal 19 UUPK ayat (1) menyebutkan bahwa Pelaku Usaha dalam hal ini pihak maskapai bertanggung jawab memberikan ganti rugi apabila terjadi kerusakan, pencemaran dan atau kerugian terhadap pihak konsumen ketika mengkonsumsi barang dan atau jasa, dalam hal ini yang dimaksud jasa angkuta udara, yang dihasilkan atau diperdagangkan. Ayat (2) mengenai Ganti rugi pada ayat (1), bisa berupa pengembalian uang atau penggantian jasa yang sejenis atau sama nilainya maksudnya ketika pihak konsumen mengalami pembatalan maka berhak mendapatkan penggantian yang senilai dengan tiket yang telah dibayarkan. Hal tersebut dijadikan acuan ketika pihak pelaku usaha ingin memberikan ganti rugi terhadap pihak konsumen. Menurut ayat (3) Mengatur mengenai pemberian ganti rugi terhadap konsumen diberikan tenggang waktu 7 (tujuh) hari terhitung sejak tanggal transaksi dilakukan.

Kemudian Pasal 23 UUPK mengatur pula apabila Pelaku usaha dalam hal ini pihak maskapai menolak memberi tanggapan dan atau tidak bersedia memenuhi ganti rugi atas tuntutan pihak konsumen sebagaimana disebutkan pada Pasal 19 ayat (1), ayat (2), ayat (3), dan ayat (4), maka dapat digugat melalui Badan Penyelesaian Sengketa Konsumen atau mengajukan gugatan ke badan peradilan di tempat kedudukan konsumen. Pada Pasal 19 UUPK juga menganut prinsip praduga lalai atau bersalah. Prinsip ini didasarkan ketika produsen dalam hal ini pihak maskapai tidak melakukan kewajibannya, dan menimbulkan kerugian pada pihak konsumen artinya produsen dapat dikatakan melakukan kesalahan. Oleh karena Pasal 19 UUPK menganut prinsip praduga lalai atau bersalah, sehingga ditetapkanlah batas waktu terhadap pernbayaran ganti kerugian selama 7 (tujuh) hari setelah tanggal transaksi telah dilakukan.

Apabila dikaitkan dengan Pasal 23 UUPK, maka batas waktu selama 7 (tujuh) hari tidak dimaksudkan untuk menjalani proses pembuktian akan tetapi hanya memberi kesempatan kepada pihak produsen untuk melakukan pembayaran atau mencari solusi, dalam hal ini termasuk penyelesaian sengketa yang dilakukan melalui pengadilan. Namun apabila pihak produsen tidak juga membayar ganti kerugian dalam batas waktu yang telah ditentukan dalam hal ini ketentuan yang tercantum dalam undang-undang, maka pihak konsumen dapat mengajukan gugatan ke Pengadilan atau penyelesaian sengketa melalui BPSK. Hal ini sesuai dengan ketentuan isi pada Pasal 45 ayat (2) dan Pasal 46 ayat (1) 
UUPK. Mengenai penyelesaian sengketa konsumen di luar pengadilan atau yang biasa disebut non litigasi dapat melalui BPSK yang merupakan satu lembaga peradilan konsumen berkedudukan pada tiap Daerah Tingkat II kabupaten serta kota di seluruh Indonesia dan juga bertugas menyelesaikan persengketaan konsumen melalui non litigasi atau di luar lembaga pengadilan umum.

Kebijakan pengembalian tiket pesawat yang dibatalkan dalam bentuk voucher merupakan kebijakan yang memenuhi win-win solution sebagai upaya mencegah terjadinya kerugian bagi kedua belah pihak. Namun demikian, dalam upaya mencegah terjadinya sengketa antara konsumen dengan pihak maskapai terkait dengan keberlakuan voucher, sebaiknya keberlakuan voucher dapat terus diperpanjang setiap tahun hingga pemerintah mengumumkan bahwa pandemi covid-19 telah berubah menjadi endemi, yang artinya virus tersebut tetap ada, namun dengan jumlah kasus yang rendah.

Mengenai penerapan tanggung jawab pelaku usaha atas pembatalan penerbangan dapat menurut Permenhub No. 89 Tahun 2015 Namun untuk penerapan tanggung jawab pihak pelaku usaha atas kerugian materiil maupun kerugian immaterial yang dialami oleh pihak konsumen diatur dalam UUPK yang secara tegas mengatur bentuk pertanggungjawaban pihak pelaku usaha atas kerugian yang dialami oleh konsumen. Namun kerugian yang dialami oleh pihak konsumen pun perlu dibuktikan sehingga ada ganti kerugian yang seimbang sehingga juga tidak merugikan pihak pelaku usaha.

\section{Ganti Rugi Terhadap Konsumen Yang Tiket Pesawatnya Dibatalkan Pada Masa Pandemi Covid-19 Menurut Pasal 9 Ayat (1) Huruf f Permenhub No. PM 89 Tahun 2015}

Kegiatan transportasi udara secara normatif tunduk terhadap ketentuan dalam Menurut Pasal 1 angka 1 UU No. 1 Tahun 2009 tentang Penerbangan. ${ }^{23}$ Berdasarkan Pasal 1 angka 20 UU No. 1 Tahun 2009 tentang Penerbangan. ${ }^{24}$ Mengenai terselenggaranya pengangkutan udara penumpang merupakan hal terpenting yang diperhitungkan oleh pihak maskapai penerbangan dalam hal untuk mendapatkan keuntungan. Penumpang yang menggunakan jasa angkutan penerbangan perlu dilindungi hak-haknya terutama hak untuk mendapatkan ganti kerugian ketika penumpang mengalami kecelakaan atau

\footnotetext{
${ }^{23}$ Pasal 1 angka 1 Undang-Undang Nomor 1 Tahun 2009 tentang Penerbangan.

24 Pasal 1 angka 20 Undang-Undang Nomor 1 Tahun 2009 tentang Penerbangan.
} 
kerusakan atau kehilangan bagasi atau keterlambatan pada jadwal penerbangan. ${ }^{25}$

Apabila pihak penumpang dalam hal ini selaku konsumen merasa dirugikan karena adanya pembatalan tiket pesawat yang telah dibayarkan maka pihak perusahaan yang bersangkutan memiliki kewajiban menurut ketentuan hukum untuk memberikan sejumlah ganti kerugian. hal ini dikarenakan antara pihak pelaku usaha jasa angkutan dan pihak konsumen atau penumpang terikat pada perjanjian dalam hukum pengangkutan. ${ }^{26}$

Permasalahan timbul ketika pembatalan penerbangan terjadi karena adanya pandemi Covid-19, maka dalam hal ini pihak pelaku usaha penerbangan memberikan hak konsumen dalam pengembalian uang tiket tidak dalam bentuk uang, tapi melainkan memberikan dalam bentuk voucher. Hal tersebut sebagaimana yang terjadi pada kasus pengembalian sejumlah uang digantikan dengan menggunakan FOP Voucher di maskapai Lion Air dan juga Garuda Indonesia.

Pengembalian tersebut yang dilakukan maskapai Lion Air dan juga Garuda Indonesia dengan mengganti menggunakan FOP Voucher, dalam rangka memenuhi kewajiban pelaku usaha.

Sebab disebutkan pula menurut Pasal 1320 KUHPerdata terkait dengan syarat sahnya suatu perjanjian, yaitu: Pertama, Adanya kesepakatan para pihak, pada Pasal 1338 KUHPerdata. ${ }^{27} \mathrm{Hal}$ tersebut merupakan asas konsensualisme, maksudnya baik pihak pelaku usaha maupun pihak konsumen perlu ada kesepakatan.

Untuk memenuhi kewajibannya dalam rangka memberikan ganti rugi atas pembatalan tiket pesawat maka berdasarkan data bahwa Lion Air mengeluarkan kebijakan yang tertuang dalam surat bernomor 003/AGTNEWS/JOGAM/IV/2020JT/IW/ID, menyebutkan bahwa pihak maskapai hanya memberikan voucher dan dapat digunakan untuk penerbangan di lain waktu. Hal yang sama juga dilakukan oleh pihak maskapai Garuda Indonesia. Namun, pengembalian sejumlah uang pembatalan penerbangan dalam bentuk voucher apabila ditolak oleh pihak konsumen maka hal ini menjadi satu permasalahan tersendiri dan perlu solusi atau komunikasi para pihak dalam menyelesaikannya.

25 Annalisa Yahanan Norsuhaida Che Musa, "Tanggung Jawab Pengangkut Udara Terhadap Penumpang”, Mimbar Hukum, Volume 22, Nomor 2, Juni 2010, hlm. 234.

26 Abdulkadir Muhammad, Loc.Cit.

${ }^{27}$ J. Satrio, Loc.Cit. 
KRTHA BHAYANGKARA | Volume 15 Number 2, December 2021

Kewajiban pengangkut untuk bertanggung jawab atas kerugian karena keterlambatan juga disebut dalam Pasal 146 UU No. 1 Tahun 2009 tentang Penerbangan yang menyebutkan bahwa Pengangkut dalam hal ini pelaku usaha bertanggung jawab atas kerugian yang diderita oleh pihak konsumen karena keterlambatan pada angkutan penumpang kecuali apabila pengangkut dalam hal ini pihak maskapai dapat membuktikan bahwa keterlambatan tersebut disebabkan oleh faktor cuaca dan teknis operasional. Menurut penjelasan dalam Pasal 146 UU No.1 Tahun 2009 di sebutkan yang dimaksud dengan "faktor cuaca" seperti terjadnya hujan lebat kemudian petir, badai, kabut, asap dan jarak pandang di bawah standar minimal atau termasuk juga kecepatan angin yang melampaui standar maksimal yang dapat mengganggu keselamatan pada saat penerbangan.

Menurut Permenhub No. 89 Tahun 2015 mengatur bahwa pembatalan penerbangan (cancelation of flight) merupakan tidak beroperasinya suatu penerbangan sesuai dengan rencana penerbangan yang telah ditentukan. Pada Pasal 2 Peraturan tersebut menyatakan keterlambatan penerbangan pada badan usaha angkutan udara niaga berjadwal terdiri dari: keterlambatan penerbangan atau tidak terangkutnya penumpang dengan alasan bahwa kapasitas pesawat udara serta pembatalan penerbangan.

Pada Pasal 3 Peraturan tersebut menyatakan Dalam hal terjadi keterlambatan penerbangan maka Badan Usaha Angkutan Udara wajib memberikan kompensasi atau ganti rugi kepada pihak konsumen dalam hal ini penumpangnya. Mengenai keterlambatan penerbangan dapat dikelompokkan menjadi 6 (enam) kategori keterlambatan, seperti:

1) Kategori satu, jika keterlambatan 30 (tiga puluh) menit sampai dengan 60 (enam puluh) menit;

2) Kategori dua, keterlambatan 61 (enam puluh satu) menit sampai dengan 120 (seratus dua puluh) menit;

3) Kategori tiga, keterlambatan 121 (seratus duapuluh satu) menit sampai dengan 180 (seratus delapan puluh) menit;

4) Kategori empat, keterlambatan 181 (seratus delapan puluh satu) menit sampai dengan 240 (dua ratus empat puluh) menit;

5) Kategori lima, keterlambatan lebih dari 240 (dua ratus empat puluh) menit; dan

6) Kategori 6, pembatalan penerbangan.

Berdasarkan Pasal 9 ayat (1) huruf f Peraturan tersebut menyatakan kompensasi yang wajib diberikan oleh pihak maskapai selaku Badan Usaha Angkutan Udara akibat adanya pembatalan penerbangan seperti mengalihkan ke penerbangan berikutnya atau 
mengembalikan sejumlah biaya atau uang untuk membeli tiket yang telah dikeluarkan oleh pihak konsumen. Berdasarkan ketentuan yang tercantum dalam Pasal 10 ayat (1) dan ayat (2) Permenhub No. 89 Tahun 2015 menyebutkan antara lain:

(1) Pihak maskapai penerbangan selaku badan usaha ketika melakukan pengembalian seluruh biaya tiket sebagaimana dimaksud dalam Pasal 9 huruf f dan g, jika pembelian tiket dilakukan melalui transaksi tunai, maka badan usaha angkutan udara atau pihak pelaku usaha wajib mengembalikan secara tunai pada saat pihak konsumen atau penumpang melaporkan diri kepada pihak maskapai atau badan usaha angkutan udara.

(2) Pihak maskapai atau badan Usaha ketika melakukan pengembalian seluruh biaya tiket sebagaimana yang tercantum dalam Pasal 9 huruf $f$ dan $g$ apabila pembelian tiket dilakukan melalui transaksi non tunai atau melalui kartu kredit, maka pihak pelaku usaha atau badan usaha angkutan udara wajib mengembalikan secara transfer ke rekening kartu kredit paling lambat 30 (tiga puluh) hari kalender.

Berdasarkan ketentuan tersebut, penumpang selaku konsumen berhak mendapatkan pengembalian uang seluruh biaya tiket. Meskipun berdasarkan ketentuan yang tercantum dalam Pasal 12 ayat (3) Permenhub No. 89 Tahun 2015 mengatur bahwa pemberian ganti rugi dapat diberikan dalam bentuk uang tunai atau voucher atau melalui transfer rekening, namun demikian voucher yang dimaksud adalah voucher yang dapat diuangkan, dan pengembalian dana tersebut selambat-lambatnya $3 \times 24$ jam sejak keterlambatan dan pembatalan penerbangan terjadi.

Permenhub Republik Indonesia No. PM 25 Tahun 2020 Tentang Pengendalian Transportasi Selama Masa Mudik Idul Fitri Tahun 1441 Hijriah dilakukan Dalam Rangka Pencegahan Penyebaran Covid-19. Terhadap pembatalan penerbangan tersebut, maka pihak maskapai sebagai badan usaha memiliki kewajiban untuk melakukan pengembalian sejumlah uang kepada pihak konsumen atau penumpang sebagaimana yang telah diatur dalam Pasal 24 yang menyebutkan badan usaha angkutan udara atau pihak maskapai dalam mengembalikan biaya tiket angkutan udara dapat dilakukan dengan cara sebagai berikut:

1) pertama, dengan melakukan penjadwalan ulang atau istilah lainnya re-schedule, calon penumpang yang telah memiliki tiket tanpa dikenakan biaya;

2) kedua, melakukan perubahan rute penerbangan atau istilah lainnya re-route, calon penumpang yang telah memiliki tiket tanpa dikenakan biaya dalam hal 
rute pada tiket tidak bertujuan keluar dan/atau masuk wilayah sebagaimana maksud dalam Pasal 2;

3) ketiga, mengkompensasikan besaran nilai biaya jasa angkutan udara menjadi perolehan poin dalam keanggotaan badan usaha angkutan udara yang bisa digunakan untuk membeli produk yang ditawarkan oleh badan usaha angkutan udara

4) kempat, memberikan kupon tiket atau istilah lainnya voucher ticket sebesar nilai biaya jasa angkutan udara sesuai dengan tiket yang dibeli oleh penumpang dapat digunakan untuk membeli lagi tiket penerbangan yang lain serta berlaku paling singkat setahun dan dapat diperpanjang paling banyak satu kali.

Pengembalian dalam bentuk penjadwalan ulang maupun kupon tiket atau voucher ticket mengacu kesepakatan antara pihak badan usaha angkutan udara dengan pihak calon penumpang. Terhadap fakta bahwa maskapai Lion Air dan Garuda Indonesia yang mengembalikan dana pembatalan penerbangan berupa voucher karena adanya pandemi Covid-19, maka menjadi pertanyaan adalah, apakah pandemi Covid-19 dapat dinyatakan sebagai overmacth, sehingga maskapai Lion Air dan Garuda Indonesia pengembalian dana pembatalan penerbangan berupa voucher dapat dibenarkan?

Pengaturan mengenai force majeure (overmacth) terdapat dalam Pasal 1244 KUHPerdata, Pasal 1245 KUHPerdata, Pasal 1444 KUHPerdata dan Pasal 1445 KUHPerdata. Dalam pasal tersebut memang tidak menyebutkan definisi secara eksplisit apa arti force majeure, namun melalui pasal tersebut dapat mengindentifikasi unsur-unsur keadaan dapat dikatakan force majeure.

Unsur-unsur force majenre menurut Pasal 1245 KUHPerdata, Pasal 1444 KUHPerdata dan Pasal 1445 KUHPerdata apabila dikaitkan dengan pandemi Covid-19, yaitu:

1) Unsur "peristiwa yang tidak terduga".

2) Unsur "tidak dapat dipertanggungjawabkan kepada debitur".

3) Unsur "tidak ada itikad buruk dari debitur".

4) Unsur "keadaan itu menghalangi debitur berprestasi".

Terkait adanya Pandemi Covid-19 apakah menghalangi debitur untuk berprestasi, itu sifatnya kasuitis dan perlu dibuktikan. Karena tidak semua debitur masa pandemi terhalang untuk memenuhi prestasi. Berdasarkan hal tersebut, untuk menilai apakah debitur dapat menyatakan mengalami keadaan force majeure. 
Pembatalan tiket pesawat tidak bersifat permanen, melainkan hanya bersifat sementara waktu saja, yaitu selama terjadinya wabah pandemi Covid-19. Berbeda dengan force majeure yang bersifat absolut, dimana sampai kapanpun suatu prestasi yang terbit dari kontrak tidak mungkin dilakukan lagi. Misalnya, ketika terjadi bencana alam gempa bumi di suatu wilayah tertentu yang mengakibatkan objek dan subjek dalam perjanjian menjadi musnah diluar dugaan.

Berdasarkan wawancara dengan Bapak Fatih selaku pihak call center Garuda mengatakan bahwa:

"Berdasarkan kebijakan pihak maskapai, bahwa voucher tiket pesawat berlaku hingga 31 Desember 2022, dan apabila voucher tersebut belum digunakan hingga tanggal 31 Desember 2022, maka akan ada kebijakan lebih lanjut. Selain daripada itu, voucher merupakan voucher bernama, namun dapat dialihkan kepada pihak lain dengan syarat adanya surat kuasa dari pemilik voucher. ${ }^{28}$

Hal yang sama juga dinyatakan oleh pihak travel tiket.com yang menyatakan bahwa: "Jika dalam jangka waktu 1 (satu) tahun tidak menggunakan vouchernya, maka dapat menghubungi terlebih dahulu pihak maskapai yang digunakan, apakah bisa diperpanjang untuk penggunaan vouchernya ataukah memiliki kebijakan lainnya." 29

Hasil wawancara diperoleh pada travel Traveloka mengatur terkait dengan pengembalian tiket pesawat dalam bentuk lain, yaitu travel credit yang dalam prosesnya membutuhkan waktu hingga 90 (sembilan puluh) hari atau bahkan lebih karena dibutuhkan koordinasi menyeluruh antara Traveloka dengan pihak maskapai. ${ }^{30}$ Berdasarkan hal tersebut, maka pengembalian dana pembatalan penerbangan berupa voucher oleh maskapai Lion Air dan Garuda Indonesia tidak bertentangan dengan hukum, Mengenai kebijakan pengembalian tiket pesawat yang dibatalkan dalam bentuk voucher merupakan kebijakan yang memenuhi win-win solution dengan persyaratan, karena diketahui bahwa efek dari pandemi covid-19 dirasakan hampir seluruh aspek, tidak terkecuali dunia penerbangan. Apabila pengembalian tiket pesawat dipaksakan dalam bentuk uang sebagaimana diatur dalam Pasal 9 ayat (1) huruf f Peraturan Menteri Perhubungan Nomor PM 89 Tahun 2015, maka perusahaan maskapai dapat tutup permanen. Meskipun demikian, tidak adanya kepastian keberlakuan voucher yang

${ }^{28}$ Wawancara Penulis dengan Bapak Fatih selaku pihak call center Garuda via telepon pada tanggal 26 Agustus 2021.

${ }^{29}$ Wawancara Penulis dengan pihak call center tiket.com via chat pada tanggal 26 Agustus 2021.

${ }^{30}$ Wawancara Penulis dengan pihak call center Traveloka via chat pada tanggal 26 Agustus 2021. 
melewati masa berlakunya, tentunya berpotensi akan terjadi permasalahan hukum berupa kerugian bagi pihak konsumen.

Hal tersebut dikarenakan situasi pandemi covid-19 tidak dapat diperkirakan kapan akan berakhir, sedangkan pemerintah terus menggiatkan pembatasan mobilitas masyarakat. Oleh karena itu, secara umum, pengembalian tiket pesawat dalam bentuk voucher bertentangan dengan unsur subjektif dalam Pasal 1320 KUHPerdata, yaitu unsur kesepakatan, sehingga dapat dibatalkan. Hal tersebut dikarenakan pengembalian dana pembatalan penerbangan berupa voucher oleh maskapai Lion Air dan Garuda Indonesia tidak disepakati oleh konsumen dan keberlakuan voucher yang tidak pasti setelah batas waktu keberlakuan terlewati, sehingga apabila konsumen merasa kebijakan maskapai tersebut mengakibatkan kerugian bagi konsumen, maka konsumen dapat melakukan upaya hukum yang Penulis jabarkan pada pembahasan permasalahan kedua.

\section{KESIMPULAN}

Terhadap konsumen yang tiket pesawatnya dibatalkan pada masa pandemi covid-19 berdasarkan UUPK berhak untuk mendapatkan ganti rugi. Ganti rugi tersebut mengacu pada ketentuan Pasal 9 ayat (1) huruf f Peraturan Menteri Perhubungan Nomor PM 89 Tahun 2015. sedangkan kebijakan ganti rugi oleh pelaku usaha berupa pengembalian dalam bentuk voucher yang dapat dipergunakan untuk jadwal dan rute lain selama satu tahun penuh. Mengenai kebijakan pengembalian dana pembatalan penerbangan berupa voucher oleh maskapai Lion Air dan Garuda Indonesia diharapkan menjadi sebuah solusi yang baik dalam rangka memenuhi hak-hak konsumen. Namun apabila konsumen merasa kebijakan maskapai tersebut mengakibatkan kerugian, maka konsumen dapat melakukan upaya hukum sesuai dengan ketentuan perundang-undangan.

\section{SARAN}

Sebaiknya informasi pengembalian tiket pesawat dengan voucer tersebut perlu di beritahukan kepada pihak konsumen diawal ketika melakukan pembelian tiket pesawat dimasa pandemi covid-19 agar konsumen dapat mengetahui resikonya dan seperti apa mengantisipasinya. dan perlu dibuatnya peraturan serta seperti apa teknisnya dapat di infokan kepada pihak konsumen dengan memanfaatkan teknologi sehingga memberikan kemudahan kepada pihak konsumen. 
KRTHA BHAYANGKARA | Volume 15 Number 2, December 2021

\section{DAFTAR PUSTAKA}

\section{Buku}

Badrulzaman, Mariam Darus, 2015, Hukum Perikatan Dalam KUHPerdata, Bandung: Citra Aditya Bakti.

H.S., Salim, 2003, Hukum Kontrak Teori dan Teknik Penyusunan Kontrak, Jakarta: Sinar Grafika.

Hadjon, Philipus M., 1987, Perlindungan Hukum Bagi Rakyat di Indonesia, Surabaya: PT. Bina Ilmu.

Margono, Suyud, 2002, Pembaharuan Perlindungan Hukum Merek, Jakarta: Novindo Pustaka Mandiri.

Marzuki, Peter Mahmud, 2009, Penelitian Hukum, Jakarta: Kencana.

Muljadi, Kartini dan Gunawan Widjaja, 2002, Perikatan Yang Labir Dari Perjanjian, Jakarta: PT Raja Grafindo Persada.

Nasution, AZ., 1995, Konsumen dan Hukum: Tinjauan Sosial, Ekonomi dan Hukum pada Perlindungan Konsumen Indonesia, Jakarta: Pustaka Sinar Harapan.

Nasution, M.N., 2007, Manajemen Transportasi, Bogor: Ghalia Indonesia.

Purwosutjipto, 1991, Pengertian Pokok. Hukum Dagang Indonesia 3: Hukum Pengangkutan, Yogyakarta: Djambatan.

Setiawan, R., 1987, Pokok-Pokok. Hukum Perikatan, Bandung: Bina Cipta.

Soekanto, Soerjono dan Sri Mamudji, 2006, Penelitian Hukum Normatif, Suatu Tinjanan Singkat, Jakarta: PT. Raja Grafindo Persada.

Soekardono, 1981, Hukum Dagang Jilid 1, Jakarta: Rajawali Press.

Soeroso, 2006, Pengantar Ilmu Hukum, Jakarta: Sinar Grafika.

Subekti, R., 2005, Hukum Perjanjian, Cetakan ke-21, Jakarta: PT Intermasa. , 1984, Pokok-Pokok Hukum Perdata, Jakarta: PT. Intermasa.

Suwarno, 2001, Tata Operasi Darat, Jakarta: Grasindo.

\section{Jurnal:}

Budimah, B., 2018, "Pembatalan Tiket oleh Calon Penumpang Maskapai Penerbangan di Indonesia," Maleo Law Journal 2, No. 1.

Herman, Herman et al., 2020, "Tinjauan Yuridis Mengenai Dampak COVID-19 Terhadap Pemutusan Hubungan Kerja," Halu Oleo Law Review Vol. 4 Nomor 2.

Supriatna, 2020 "Wabah Corona Virus Disease COVID-19 Dalam Pandangan Islam", Jurnal Sosial \& Budaya, Vol. 7 No. 6, 555-564.

Wiradipradja, Saefullah, 2006, "Tanggung Jawab Perusahaan Penerbangan Terhadap Penumpang Menurut Hukum Udara Indonesia”, Jurnal Hukum Bisnis Vol 25,.

\section{Peraturan Perundang-Undangan:}

Undang-Undang Dasar Negara Republik Indonesia Tahun 1945 Amandemen IV. 
Kitab Undang-Undang Hukum Perdata (Burgerlijk Wetboek).

Undang-Undang Nomor 8 Tahun 1999 tentang Perlindungan Konsumen.

Peraturan Menteri Perhubungan Nomor PM 89 Tahun 2015 Tentang Penanganan Keterlambatan Penerbangan (Delay Management) Pada Badan Usaha Angkutan Udara Niaga Berjadwal di Indonesia.

Peraturan Menteri Perhubungan Nomor PM 185 Tahun 2015 tentang Standar Pelayanan Penumpang Kelas Ekonomi Angkutan Udara Niaga Berjadwal Dalam Negeri.

Keputusan Presiden Nomor 12 Tahun 2020 Tentang Penetapan Bencana Non Alam Penyebaran Coronavirus Disease 2019 (COVID-19) Sebagai Bencana Nasional (selanjutnya disebut Keppres 12/2020) Pada 13 April 2020.

\section{Internet:}

Aditya, Nicholas Ryan, “Netizen Keluhkan Refund Tiket Tiket Pesawat Berupa Voucher Asosiasi Harap Maskapai”, https:/ travel.kompas.com/read/2020/04/27/083000327/ netizen-keluhkanrefund-tiket-pesawat-berupa-voucer-asosiasi-harap-maskapai?page $=$ all.,

Anwar, Muhammad Chairul, "Curhat Penumpang Pesawat Batal Terbang Uang Pun Nyangkut", $\quad$ https://www.cnbcindonesia.com/news/20200420174532-4153199/curhat-penumpang-pesawat-batal-terbang-uang-pun-nyangkut.,

CNN Indonesia, "Lika Liku Istilah Jokowi Dari PSBB Hingga Mini Lockdown", https:// www.cnnindonesia.com/nasional/20200930061801-20-552537/ lika-lik.u-istilah-jokowidari-psbb-hingga-mini-lockdown, 